\title{
Controlled Breeding of Asian Catfish Clarias batrachus using Pituitary Gland Extracts and Ovaprim at different Temperatures, Latency Periods and their Early Development
}

Kishore Dhara and Nimai Chandra Saha*

P.G. Department of Zoology, Barasat Govt. College, 10 K N C Road, Barasat, Kolkata-700124, India

\begin{abstract}
Present study was conducted on induced breeding of commercially important Clarias batrachus due to the non-availability of its quality seeds from the natural resources for environmental degradation, shrinkage of natural breeding ground and illegal killing of juveniles and brood fishes. The aim of the study was to achieve success in fertilization and hatching using various doses of different inducing agents at different temperatures and latency periods followed by stripping method. In this study the developmental stages of fish (fertilized egg to $45^{\text {th }}$ day old fish) were characterized chronologically. A trial was also made to optimize the survival rate of young developing fish upto $45^{\text {th }}$ day by manipulating their feeding schedule and environmental conditions. The breeding experiments were done with pituitary gland extracts ( 40 and $120 \mathrm{mg} / \mathrm{kg}$. body weight for female and 25 and $50 \mathrm{mg} / \mathrm{kg}$. body weight for male) and Ovaprim ( 0.8 and $2.0 \mathrm{ml} / \mathrm{kg}$ body weight for female and 0.4 and $1.0 \mathrm{ml} / \mathrm{kg}$ body weight for male) at $26^{\circ}, 28^{\circ}$ and $30^{\circ} \mathrm{C}$. The highest rates of fertilization $(80 \%)$ and hatching $(71 \%)$ of eggs were recorded in Clarias batrachus injected with carp pituitary gland extracts @ $50 \mathrm{mg} / \mathrm{kg}$ body weight of male and $120 \mathrm{mg} / \mathrm{kg}$ body weight of female at $28^{\circ} \mathrm{C}$ with a latency period of 15 hours. The fertilization and hatching rates were $77 \%$ and $65 \%$ respectively at $28^{\circ} \mathrm{C}$ at the higher doses of Ovaprim. The highest survival rate (82.5\%) of developing fish was achieved supplying zooplankton as live feed upto $12^{\text {th }}$ day followed by alternate supply of zooplankton, boiled egg with vitamin $\mathrm{C}$ and chopped tubifex from $13^{\text {th }}$ to $45^{\text {th }}$ day of rearing in indoor polyvinyl chloride tray with minimum fluctuation in temperature and dissolved oxygen.
\end{abstract}

Keywords: Pituitary gland extracts; Ovaprim; Clarias batrachus; Breeding; Fertilization; Hatching; Development

\section{Introduction}

The Asian catfish, Clarias batrachus (Linnaeus, 1758) commonly known as "magur" has a fairly common distribution in fresh and brackish waters of the plains throughout India. It has high commercial importance in India, Bangladesh, Thailand, Philippines, Myanmar and China due to its good taste, high protein (15.0\%) and iron content (710 mg/100 gm tissue) with markedly low value of fat (1.0\%) as well as therapeutic application [1-4]. The Central Board of fisheries, India suggested that emphasis should be given on catfish farming specially magur farming which has been identified as one of the potential national priority in Indian aquaculture [5]. In the natural environment, it spawns once a year [6]. The Spawning period is July-August $[5,6]$. The major constraint in the culture of magur is the non-availability of quality seeds from the natural resources due to environmental degradation for rapid industrialization and injudicious application of pesticides, shrinkage of natural breeding ground due to siltation, over exploitation and illegal killing of juveniles and brood fishes.

Therefore, it becomes necessary to take up breeding and larval rearing of magur in controlled conditions to meet the needs of small and medium sized entrepreneurs and local farmers. Induced spawning techniques for C. batrachus have been successfully used for seed production by few workers using various natural and synthetic agents like piscine pituitary gland extracts, Human Chorionic Gonadotropin (HCG), Ovaprim, Ovatide etc. [1,2,7-11]. Although induced breeding of $C$. batrachus is not a difficult task but main problem lies within the fertilization, hatching success and early development of the fish. Large scale mortality occurs in the early developing stage after absorption of yolk sac [12]. The reports on the breeding performance of C. batrachus by various stimulants using different doses are scanty $[2,8-10,13,14]$. The information on the effects of temperatures and the latency period on the breeding efficiency of $C$. batrachus are also very rare $[10,11]$.
For expansion of catfish culture, knowledge of early development of young fish is imperative [15]. But there are sparse literature reports on the chronological early development of C. batrachus [16,17]. Moreover, high level survival of developing C. batrachus is another challenge for the hatchery operators and fish farmers as no standardized protocol of feeding to developing fish has so far been evolved.

In the present study, a trial was made for controlled breeding of Asian catfish Clarias batrachus at different temperatures using various doses of pituitary gland extracts and Ovaprim followed by stripping method to get the higher success rate in respect of fertilization and hatching. The latency period was also manipulated to get better performance in breeding in the present investigation. In addition, the developing young fish were also reared upto $45^{\text {th }}$ day in indoor and outdoor conditions using live and artificial feed for optimizing their survivality.

\section{Materials and Methods}

\section{Test organism}

In the present study, disease free healthy gravid male (average length

*Corresponding author: Nimai Chandra Saha, Professor of Zoology, Pos Graduate Dept. of Zoology, Barasat Govt. College, $10 \mathrm{~K} \mathrm{~N} \mathrm{C} \mathrm{Road,} \mathrm{Barasat,}$ Kolkata-700124, India; Tel: +91 9051342474, +91 9475945780; Fax: (033) 2562 5053; E-mail: mr.nsaha@rediffmail.com

Received March 30, 2013; Accepted May 24, 2013; Published June 04, 2013

Citation: Dhara K, Saha NC (2013) Controlled Breeding of Asian Catfish Clarias batrachus using Pituitary Gland Extracts and Ovaprim at different Temperatures, Latency Periods and their Early Development. J Aquac Res Development 4: 186 doi:10.4172/2155-9546.1000186

Copyright: @ 2013 Dhara K, et al. This is an open-access article distributed unde the terms of the Creative Commons Attribution License, which permits unrestricted use, distribution, and reproduction in any medium, provided the original author and source are credited. 
Citation: Dhara K, Saha NC (2013) Controlled Breeding of Asian Catfish Clarias batrachus using Pituitary Gland Extracts and Ovaprim at different Temperatures, Latency Periods and their Early Development. J Aquac Res Development 4: 186 doi:10.4172/2155-9546.1000186

Page 2 of 9

$26 \pm 1.5 \mathrm{~cm}$ and average weight $160 \pm 5 \mathrm{gm}$ ) and female (average length $25 \pm 2.7 \mathrm{~cm}$ and average weight $220 \pm 7 \mathrm{gm}$ ) Clarias batrachus (Order: Siluriformes; Family: Clariidae) were used for induced breeding. The selection of the gravid fish was made on the basis of external morphological features [6,18]. Gravid female fish were identified by the presence of soft swollen belly with short, round, button shaped and slit like genital papilla along with reddish vent (Figure 1). Prime maturity of the female was determined by examining the size uniformity of the eggs released by the gentle pressure on the swollen abdomen. Fully gravid males were identified by their slender and streamlined body with conical and elongated genital papilla having pointed reddish tip (Figure 2 ). They were collected from the local ponds and were acclimatized in the laboratory condition for 48 hours prior to breeding operation in the glass aquarium $(120 \mathrm{~cm} \times 45 \mathrm{~cm} \times 45 \mathrm{~cm})$ filled with unchlorinated, iron free tap water $(\mathrm{pH} 7.0 \pm 0.13$, free carbon dioxide $10.57 \pm 2.1 \mathrm{mg} / 1$, dissolved oxygen $5.85 \pm 0.92 \mathrm{mg} / \mathrm{l}$, total alkalinity $150 \pm 5.07 \mathrm{mg} / \mathrm{l}$ as $\mathrm{CaCO}_{3}$ and hardness $116 \pm 6.70 \mathrm{mg} / \mathrm{l}$ as $\mathrm{CaCO}_{3}$ ) having aeration facilities. During acclimatization male and female fishes were kept in separate aquaria and no feed was supplied.

\section{Inducing agents}

Pituitary glands were collected from mature freshly dead carp fish and extracts as natural inducing agent were made following the method described by Bhowmick [19]. Ovaprim, a synthetic inducing agent is a product of Syndel Laboratories Ltd. Vancouver, Canada, marketed by Glaxo, India. It is a combination of $20 \mu \mathrm{g}$ salmon gonadotropin

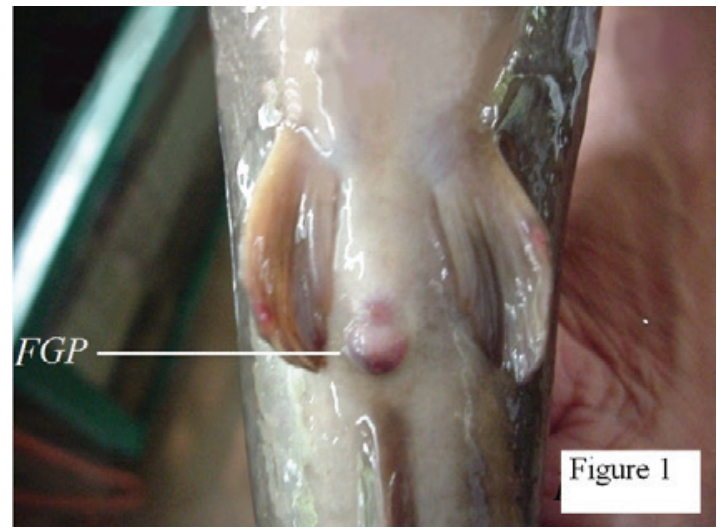

Figure 1: Ventral view of gravid female $C$. batrachus showing female genital papilla (FGP).

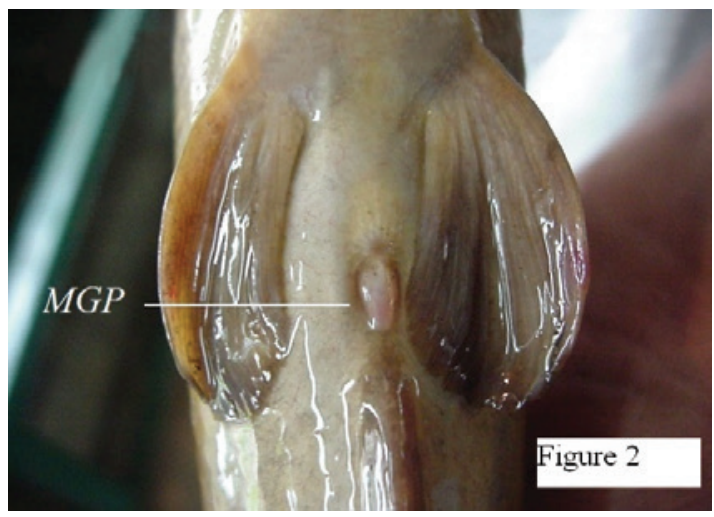

Figure 2: Ventral view of gravid male $C$. batrachus showing male genital papilla (MGP).

\begin{tabular}{|l|l|l|l|c|}
\hline $\begin{array}{l}\text { Name of } \\
\text { Stimulant }\end{array}$ & Dose & \multicolumn{4}{l|}{ Mean No. of stripped out eggs/Female } \\
\cline { 3 - 5 } & & $\mathbf{2 6}^{\circ} \mathbf{C}$ & $\mathbf{2 8}^{\circ} \mathbf{C}$ & $\mathbf{3 0}^{\circ} \mathbf{C}$ \\
\hline $\begin{array}{l}\text { Pituitary glands } \\
\text { extract }\end{array}$ & $40 \mathrm{mg} / \mathrm{kg}$ & $4356^{\mathrm{am}} \pm 79$ & $4460^{\mathrm{am}} \pm 51$ & $4476^{\mathrm{am}} \pm 36$ \\
\hline Ovaprim & $120 \mathrm{mg} / \mathrm{kg}$ & $5440^{\mathrm{dm}} \pm 47$ & $5655^{\mathrm{dn}} \pm 58$ & $5591^{\mathrm{dn}} \pm 62$ \\
\hline & $0.8 \mathrm{ml} / \mathrm{kg}$ & $4573^{\mathrm{bm}} \pm 47$ & $4702^{\mathrm{bm}} \pm 79$ & $4685^{\mathrm{bm}} \pm 82$ \\
\cline { 2 - 5 } & $2.0 \mathrm{ml} / \mathrm{kg}$ & $5315^{\mathrm{cm}} \pm 48$ & $5455^{\mathrm{cn}} \pm 49$ & $5432^{\mathrm{cm}} \pm 56$ \\
\hline
\end{tabular}

Table 1: Effects of stimulants on stripped out eggs of Clarias batrachus at $26^{\circ}$, $28^{\circ}$ and $30^{\circ} \mathrm{C}$

Values (mean $\pm \mathrm{SD}$ ) within columns indicated by different superscript letters $(a, b, c, d)$ and values (mean \pm SD) within rows indicated by different superscript letters $(m, n)$ are significantly different $(D M R T, p<0.05)$

\begin{tabular}{|c|c|c|c|c|c|c|}
\hline \multirow{2}{*}{\begin{tabular}{|l|}
$\begin{array}{l}\text { Latency } \\
\text { period } \\
\text { (Hours) }\end{array}$ \\
$\pm \mathrm{SD}$ \\
\end{tabular}} & \multicolumn{2}{|l|}{$26^{\circ} \mathrm{C}$} & \multicolumn{2}{|l|}{$28^{\circ} \mathrm{C}$} & \multicolumn{2}{|l|}{$30^{\circ} \mathrm{C}$} \\
\hline & $\begin{array}{l}\text { Fertilization } \\
\text { Rate (\%) } \\
\pm \text { SD }\end{array}$ & $\begin{array}{l}\text { Hatching } \\
\text { Rate (\%) } \\
\pm \text { SD }\end{array}$ & $\begin{array}{l}\text { Fertilization } \\
\text { Rate (\%) } \\
\pm \text { SD }\end{array}$ & $\begin{array}{l}\text { Hatching } \\
\text { Rate (\%) } \\
\pm \text { SD }\end{array}$ & $\begin{array}{l}\text { Fertilization } \\
\text { Rate (\%) } \\
\pm \text { SD }\end{array}$ & $\begin{array}{l}\text { Hatching } \\
\text { Rate (\%) } \\
\pm \text { SD }\end{array}$ \\
\hline $13 \mathrm{~h}$ & $48^{\mathrm{am}} \pm 7$ & $40^{\mathrm{am}} \pm 4$ & $56^{\mathrm{abm}} \pm 4$ & $45^{\mathrm{abm}} \pm 4$ & $47^{\mathrm{am}} \pm 6$ & $41^{\mathrm{am}} \pm 6$ \\
\hline $14 \mathrm{~h}$ & $66^{\mathrm{bcm}} \pm 6$ & $58^{\mathrm{cm}} \pm 4$ & $71^{\mathrm{cm}} \pm 5$ & $60^{\mathrm{cm}} \pm 5$ & $62^{\mathrm{bcm}} \pm 6$ & $62^{\mathrm{bcm}} \pm 6$ \\
\hline $15 \mathrm{~h}$ & $76^{\mathrm{cm}} \pm 9$ & $66^{\mathrm{dm}} \pm 3$ & $80^{\mathrm{dm}} \pm 5$ & $71^{\mathrm{dm}} \pm 6$ & $71^{\mathrm{dm}} \pm 6$ & $61^{\mathrm{cm}} \pm 5$ \\
\hline $16 \mathrm{~h}$ & $57^{\mathrm{abm}} \pm 6$ & $47^{\mathrm{bm}} \pm 4$ & $64^{\mathrm{bcm}} \pm 4$ & $53^{\mathrm{bcm}} \pm 4$ & $54^{\mathrm{abm}} \pm 6$ & $45^{\mathrm{abm}} \pm 7$ \\
\hline $17 \mathrm{~h}$ & $49^{\mathrm{am}} \pm 9$ & $42^{\mathrm{abm}} \pm 4$ & $50^{\mathrm{am}} \pm 5$ & $41^{\mathrm{am}} \pm 5$ & $47^{\mathrm{am}} \pm 5$ & $38^{a m} \pm 5$ \\
\hline
\end{tabular}

Table 2: Effects of latency period and temperature on the rate of fertilization and hatching of eggs of Clarias batrachus at higher dose of pituitary gland extracts (120 $\mathrm{mg} / \mathrm{kg}$ body wt of female).

Values (mean $\pm \mathrm{SD}$ ) within columns indicated by different superscript letters $(a, b, c, d)$ are significantly different (DMRT, $p<0.05)$ and values (mean \pm SD) within rows indicated by same superscript letter $(\mathrm{m})$ are not significantly different (DMRT, $p>0.05)$.

releasing hormone analogue (D-Arg6, Trp7, Leu 8, Pro9 Net) and 10 $\mathrm{mg}$ domperidone (as a dopamine receptor antagonist) dissolved in $1 \mathrm{ml}$ calibrated quantities of non-toxic organic solvent $[20,21]$.

\section{Breeding operations}

The breeding operations were conducted at three different temperatures $\left(26^{\circ}, 28^{\circ}\right.$ and $\left.30^{\circ} \mathrm{C}\right)$. Pituitary gland extracts and ovaprim were separately administered to different sets of gravid fish. The doses of carp pituitary gland extracts were 40 and $120 \mathrm{mg} / \mathrm{kg}$ body weight for female and 25 and $50 \mathrm{mg} / \mathrm{kg}$ body weight for male. Ovaprim was administered at the rate of 0.8 and $2.0 \mathrm{ml} / \mathrm{kg}$ body weight for female and 0.4 and $1.0 \mathrm{ml} / \mathrm{kg}$ body weight for male. The doses of inducing agents were selected after a series of rough finding tests (data not shown). Inducing agents were administered to separate sets of brood fishes consisting of both sexes at 1:1 ratio. The required doses of pituitary gland extracts or Ovaprim was divided into two equal volumes and were administered intramuscularly as separate injections at the same time in left \& right sides of the caudal peduncle region above the lateral line sense organ by hypodermic syringe with a small size needle (Beckton Dickinson needle No.24) at $45^{\circ}$ angle. After injection, male and female fishes were kept separately in the water filled glass aquaria. After a gap of 15 hours of injection (latency period), the males were cut open and the testes were carefully removed in intact condition. Then the testes were cut into small pieces with scissor and squeezed properly mixing with $0.9 \%$ sodium chloride $(\mathrm{NaCl})$ solution. The sperms remain in dormant condition in this suspension which was used immediately for fertilization of eggs. Simultaneously the female fish were stripped after the similar gap of 15 hours as latency period to release eggs into previously washed dry and clean enamel tray (Figure 3). For higher doses of pituitary gland extracts four additional latency periods $(13,14$, 16 and 17 hours) were also maintained before stripping at $28^{\circ} \mathrm{C}$ both for male and female fish (Table 2). For determination of total number 
Citation: Dhara K, Saha NC (2013) Controlled Breeding of Asian Catfish Clarias batrachus using Pituitary Gland Extracts and Ovaprim at different Temperatures, Latency Periods and their Early Development. J Aquac Res Development 4: 186 doi:10.4172/2155-9546.1000186

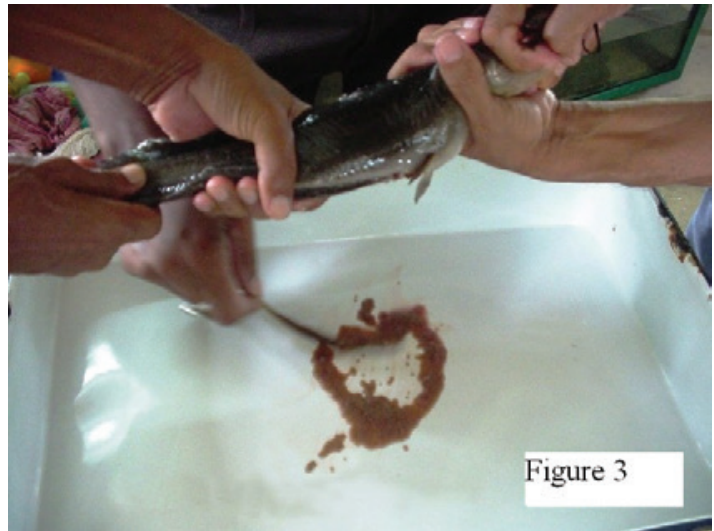

Figure 3: Stripping of eggs from female C. batrachus.

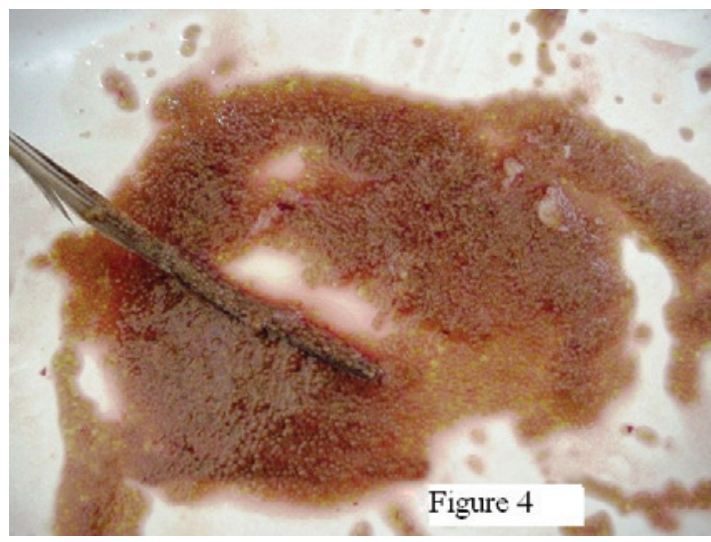

Figure 4: Mixing of eggs and milt solution with a bird's feather

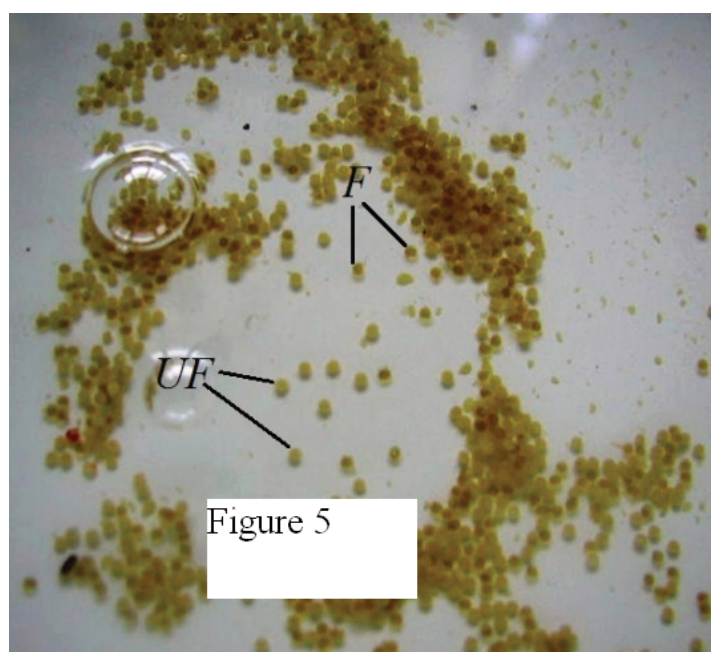

Figure 5: Fertilized (F) and unfertilized (UF) eggs of $C$. batrachus

of stripped out eggs a small portion of egg mass was randomly collected in a clear petridish from each set. The total number of stripped out eggs in each set was calculated by multiplying the total number of eggs present in a small portion of collected egg mass with the total weight of stripped out eggs (g) and then it was divided by the weight of the collected egg mass $(\mathrm{g})$. Freshly prepared milt suspension was then

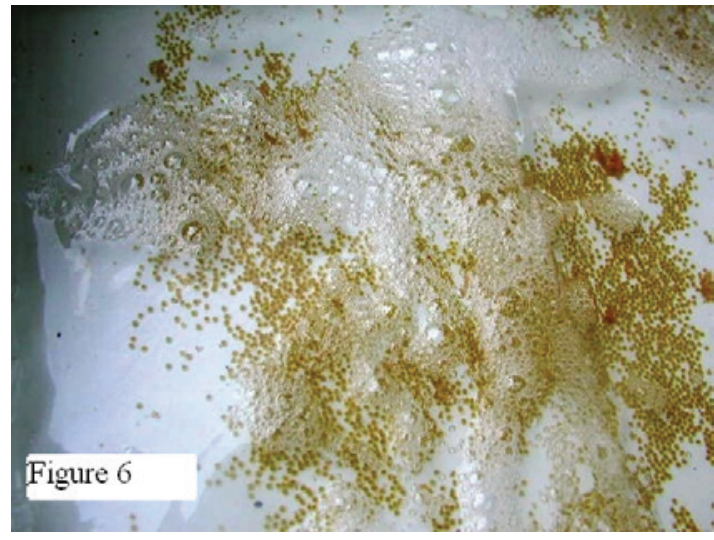

Figure 6: Washing and water hardening of fertilized eggs of $C$. batrachus

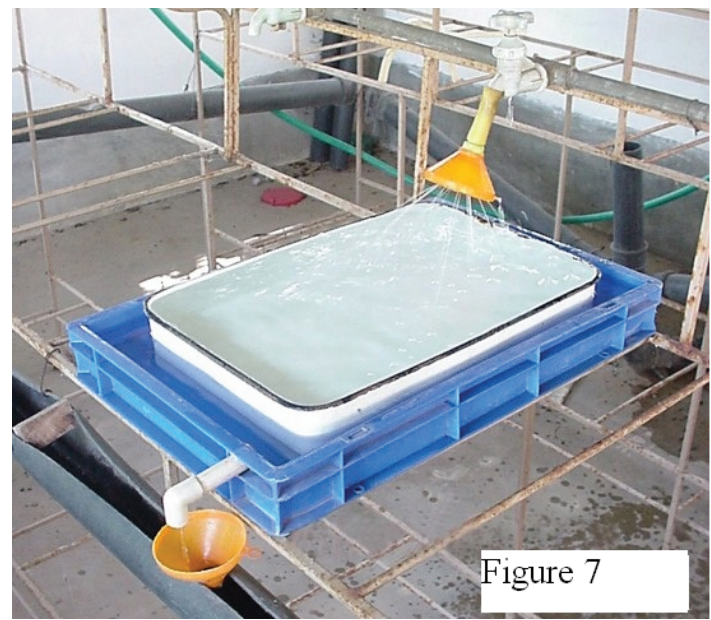

Figure 7: Hatching tray with water flow through system.

added gently to the eggs stripped after respective time of latency period by a dropper preferably within 2-3 minutes of stripping and thoroughly mixed with the help of disinfected bird's feather (Figure 4). A little freshwater was then added to activate the sperms. Then the tray was jerked gently for 2-3 minutes for proper mixing of eggs and milt. The fertilized eggs (Figure 5) were quickly washed and cleaned several times with fresh tap water for water hardening and to remove the residual milt and foam formed (Figure 6). Unfertilized eggs along with clotted blood and muscular dirt were discarded (Figure 5). For the assessment of fertilization percentage, a small portion of egg mass was randomly collected in a clear petridish filled with unchlorinated and iron free tap water for each set. The total number of eggs was counted in the collected egg mass with a magnifying glass. Then it was multiplied by one hundred and the resultant was divided by total number of collected eggs.

\section{Hatching operations}

A small scale pool was established under a shade by placing a set of polyvinyl chloride (PVC) trays $(57 \mathrm{~cm} \times 37 \mathrm{~cm} \times 10.5 \mathrm{~cm}$ ) on a platform in a flow through system of water fitted with aerator for hatching operation. Each tray was provided with two outlets at different levels. The outlets of the trays were connected to a common drainage pipe fitted at six inches down the tray. In addition, a white enamel tray (46 $\mathrm{cm} \times 30 \mathrm{~cm} \times 7.5 \mathrm{~cm}$ ) was set within each PVC tray (Figure 7). Water 


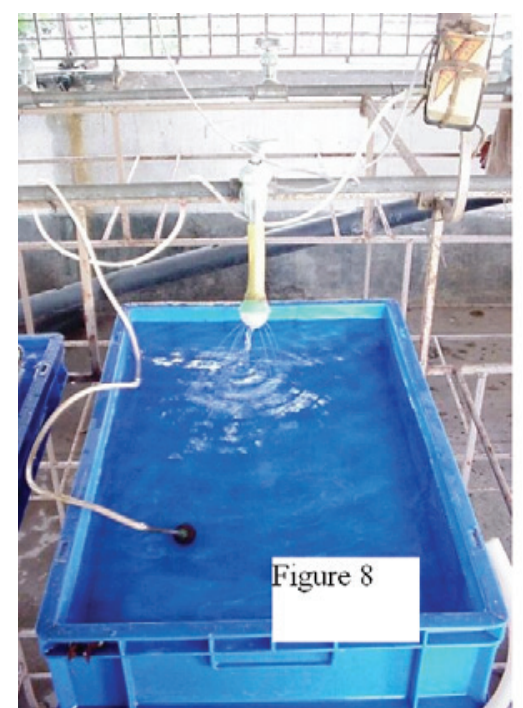

Figure 8: Rearing tray with water flow through system and aeration.

was supplied to the trays through the showers fitted with separate taps coming from a common galvanized iron (GI) pipe having $2 \mathrm{~cm}$ diameter. The common GI pipe was fixed at one foot above the trays which in turn was connected to the overhead tank. Water was released from overhead shower at a regular flow rate of about 1 to $1.5 \mathrm{l} /$ minute. The outlets of all the trays were covered with bolting silk cloth (No.60) to prevent escape of eggs. The fertilized eggs were uniformly distributed in the enamel trays at the rate of $3000 \pm 100$ eggs per tray fitted within the PVC trays having regulated water flow and continuous aeration facilities. After hatching the hatchlings were counted by eye estimation method. The hatching rate was assessed by multiplying hundred with the total number of hatchlings obtained. Then the resultant was divided by the total number of fertilized eggs.

\section{Rearing operations}

The hatching unit was also used as the rearing unit, but the inner enamel tray was removed from the system (Figure 8). The water of each tray was aerated to maintain dissolved oxygen level above $5 \mathrm{mg} / \mathrm{l}$ throughout the hatching and rearing operations. Sufficient water level was also regulated during the experiment by opening and closing the outlets.

Hatchlings were reared in the same flow through system at the rate of $2000 \pm 200 \mathrm{fish} /$ tray upto $4^{\text {th }}$ day and at the rate of $1000 \pm 200 \mathrm{fish} /$ tray upto $12^{\text {th }}$ day until the young developing fish started frequent vertical movement. The developing fish were reared both in the indoor PVC tray and outdoor cement cistern $(365 \mathrm{~cm} \times 117 \mathrm{~cm} \times 40 \mathrm{~cm})$ at the rate of 500 nos. $/ \mathrm{m}^{2}$ in a static and partial water replacement system during the period from $13^{\text {th }}$ to $45^{\text {th }}$ day. A regular water replacement $(30-50 \%)$ was done in the morning to remove faecal matter, unused food materials and dead fish, if any. The water level was maintained in between 25-35 $\mathrm{cm}$. in the cement cistern to avoid the exhaustion of developing fish during their vertical trip. Moreover, the young developing fish were treated with potassium permanganate solution at the rate of $1 \mathrm{mg} / \mathrm{l}$ of water for 10 minutes once a week from the 10th day of rearing to avoid infection. The physicochemical parameters (temperature, $\mathrm{pH}$, free carbon dioxide, total alkalinity and dissolved oxygen) of indoor and outdoor culture medium were recorded four times $(04.00,10.00,16.00$ and 22.00 hours) daily following the method described in APHA [22].
No feed was supplied upto $4^{\text {th }}$ day of rearing due to nutritive contribution of yolk material. Finely sieved zooplankton were given as preferred live feed from $5^{\text {th }}$ to $12^{\text {th }}$ day of rearing at 4 hours interval. Three different sets of feeding trials were run using three different kinds of feed at the rate of $3 \%$ of their body weight at 8 hours interval during $13^{\text {th }}$ to $45^{\text {th }}$ day of rearing both in indoor and outdoor conditions. In Set I, the fish were fed with live zooplankton during rest of the rearing period. In Set II, the boiled and sieved hen's egg with small amount of vitamin $\mathrm{C}$ was supplied as supplementary feed alternating with live zooplankton upto 20th day. The chopped tubificid worms were also used as feed followed by boiled hen's egg with vitamin $\mathrm{C}$ and zooplankton during the period from $21^{\text {st }}$ to $45^{\text {th }}$ day of rearing in Set II. The worms before their use were treated with oxytetracycline at the rate of $250 \mathrm{mg} / \mathrm{l}$ of water for 15-20 minutes to make them pathogen free. The mixture of rice bran, mustard oil cake and trash fish at the rate of 1:1:1 ratio was powered and used as artificial feed in Set III during the period from $13^{\text {th }}$ to $45^{\text {th }}$ day of rearing.

For chronological developmental study, 30 developing eggs were sampled at every 1 hour interval until hatching and thereafter 30 developing fish were sampled at every 6 hours for the next four days and then only once a day until $45^{\text {th }}$ day of development following the method of Puvaneswari et al. [15]. Measurements of egg diameter and standard length of fish were made using an ocular micrometer and other conventional methods. The total lengths of thirty randomly sampled individual fish were measured at each sampling time considering that the total length is the length from the tip of snout of fish to the end of caudal fin [23]. Similarly, total weight (wt.) of fish was measured by using electronic balance.

\section{Statistical analyses}

All values in the present experiment are expressed as the mean $\pm \mathrm{SD}$ of three replicates and were statistically analyzed by one way ANOVA (analysis of variance) followed by DMRT (Duncan's Multiple Range Test) to determine significant differences between the means [24].

\section{Results}

In the present study both male and female Clarias batrachus injected with booster doses (higher doses) of pituitary gland extracts (50 mg/kg body weight for male and $120 \mathrm{mg} / \mathrm{kg}$ body weight for female) or Ovaprim $(1.0 \mathrm{ml} / \mathrm{kg}$ body weight for male and $2.0 \mathrm{ml} / \mathrm{kg}$ body weight for female) responded well in respect of optimum maturity of gonads and stripping property. The female fish showed smooth stripping and released fully developed eggs without cluster. Testes were fully developed and swollen. A significant amount of motile and viable sperms were obtained on squeezing the testes. Total number of eggs obtained after stripping of female injected with booster doses of pituitary gland extracts and Ovaprim at all the temperatures (at $26^{\circ}$, $28^{\circ}$ and $\left.30^{\circ} \mathrm{C}\right)$ were significantly higher $(\mathrm{p}<0.05)$ than the lower doses of respective stimulants (Table 1). In addition, in booster doses of pituitary gland extracts the egg production was also significantly higher than the booster doses of Ovaprim. In the lower doses of pituitary gland extracts $(25 \mathrm{mg} / \mathrm{kg}$ body weight for male and $40 \mathrm{mg} / \mathrm{kg}$ body weight for female), stripping was smooth but ova were not developed fully in female. The ova came out in clusters. Testes were moderately developed but they were not properly swollen. At the lower doses of Ovaprim (0.4 $\mathrm{ml} / \mathrm{kg}$ body weight for male and $0.8 \mathrm{ml} / \mathrm{kg}$ body weight for female), the stripping was not smooth and ova were not fully developed in female. The swollen and fully developed testes were not also observed at this dose. Total number of stripped out eggs at $28^{\circ}$ and $30^{\circ} \mathrm{C}$ were significantly higher $(\mathrm{p}<0.05)$ than the number of eggs produced at $26^{\circ} \mathrm{C}$ 
Citation: Dhara K, Saha NC (2013) Controlled Breeding of Asian Catfish Clarias batrachus using Pituitary Gland Extracts and Ovaprim at different Temperatures, Latency Periods and their Early Development. J Aquac Res Development 4: 186 doi:10.4172/2155-9546.1000186

Page 5 of 9

injected with booster doses of pituitary gland extracts and Ovaprim (Table 1). But the number of stripped out eggs was not significantly varied $(\mathrm{p}>0.05)$ at different temperatures using the lower doses of pituitary gland extract and Ovaprim. At a particular temperature $\left(26^{\circ}\right.$ or $28^{\circ}$ or $30^{\circ} \mathrm{C}$ ), the number of stripped out eggs significantly varied $(\mathrm{p}<0.05)$ in all the doses irrespective of the stimulants.

Smooth stripping and ova without clusters were recorded at higher dose of pituitary gland extracts $(120 \mathrm{mg} / \mathrm{kg}$ body weight of female) when the latency period was maintained for 14 or 15 hours irrespective of temperatures. On the other hand, the stripping was not smooth and ova came out in clusters when stripping was made at 13 hours latency period. The ova lose their normal property in relation to shape, colour and hardiness when the fish were stripped at 16 hours and 17 hours slatency periods. Significantly higher $(\mathrm{p}<0.05)$ fertilization and hatching rates were recorded at all the temperatures at 14 hours and 15 hours latency periods using higher dose of pituitary gland extracts (Table 2). The highest percentage of fertilization and hatching rates were observed at $28^{\circ} \mathrm{C}$ when stripping was done at 15 hours of latency period.

The rate of fertilization and hatching of eggs was significantly higher $(\mathrm{p}<0.05)$ at the higher doses of pituitary gland extracts $(120 \mathrm{mg} / \mathrm{kg})$ and Ovaprim $(2.0 \mathrm{ml} / \mathrm{kg})$ at all the temperatures $\left(26^{\circ}, 28^{\circ}, 30^{\circ} \mathrm{C}\right)$ (Tables 3 and 4$)$. However, the highest rate of fertilization (80\%) and hatching (71\%) was recorded at the higher doses of pituitary gland extracts at $28^{\circ} \mathrm{C}$. On the other hand, in the lower doses of pituitary gland extracts and Ovaprim, the rate of fertilization and hatching were significantly reduced $(\mathrm{p}<0.05)$ irrespective of temperatures (Tables 3 and 4$)$. Time required for hatching after fertilization was $30 \pm 1.5$ hours, $27 \pm 0.5$ hour and $25 \pm 1.0$ hour at $26^{\circ}, 28^{\circ}$ and $30^{\circ} \mathrm{C}$ respectively irrespective of type and doses of the stimulants used.
The physicochemical parameters recorded from the rearing medium in the indoor PVC tray and outdoor cement cistern during rearing of young fish from $13^{\text {th }}$ to $45^{\text {th }}$ day are given in Table 5. A significant diurnal variation in temperature, free carbon dioxide and dissolved oxygen was recorded both in the indoor PVC tray and outdoor cistern $(\mathrm{p}<0.05)$. The temperature, free $\mathrm{CO}_{2}$ and dissolved oxygen of indoor $\mathrm{PVC}$ tray were also significantly varied from their respective values as observed in the outdoor cistern (Table 5). Consistently a higher level of dissolved oxygen concentration (5.90-6.41 mg/l) was recorded in the indoor rearing medium, but a high fluctuation in dissolved oxygen level (4.53-6.56) was observed in outdoor cistern. The diurnal fluctuations in temperature and free $\mathrm{CO}_{2}$ were also more acute in the outdoor cistern than indoor PVC tray. No significant variation was recorded in $\mathrm{pH}$ and total alkalinity in both the indoor and outdoor system.

Survival rates of young developing fish reared in indoor PVC tray and outdoor cement cistern with different sets of feeding trials were summarized in Table 6 . Significantly higher $(\mathrm{p}<0.05)$ survival rates were observed in Set II over Set I and Set III both in indoor and outdoor rearing conditions. Significantly lower $(\mathrm{p}<0.05)$ survival rate of fish was recorded in Set III irrespective of culture conditions. The developing fish showed significantly higher $(\mathrm{p}<0.05)$ survival rate in all the Sets of indoor trials over their outdoor counterparts.

The developmental stages (fertilized egg to $45^{\text {th }}$ day) of fish recorded in the present experiment are characterized chronologically:

\section{Fertilized egg}

0 hour: Egg was spherical, non-filamentous, demersal, adhesive, transparent and yellowish brown in colour with $1.80 \pm 0.05 \mathrm{~mm}$ in diameter (Figure 5).

\begin{tabular}{|c|c|c|c|c|c|c|c|c|}
\hline \multirow{4}{*}{\begin{tabular}{|l|} 
Name of stimulant \\
Pituitary gland extract
\end{tabular}} & \multirow{3}{*}{\begin{tabular}{|l|} 
Dose \\
Male \\
$25 \mathrm{mg} / \mathrm{kg}$ \\
\end{tabular}} & \multicolumn{7}{|c|}{ Mean No. of fertilized eggs and rate of fertilization (\%) } \\
\hline & & \multirow{2}{*}{$\begin{array}{l}\text { Female } \\
40 \mathrm{mg} / \mathrm{kg}\end{array}$} & \multicolumn{2}{|l|}{$26^{\circ} \mathrm{C}$} & \multicolumn{2}{|l|}{$28^{\circ} \mathrm{C}$} & \multicolumn{2}{|l|}{$30^{\circ} \mathrm{C}$} \\
\hline & & & $1994^{\mathrm{bm}} \pm 29$ & $46 \%$ & $2215^{\text {ao }} \pm 30$ & $50 \%$ & $2126^{\text {an }} \pm 35$ & $48 \%$ \\
\hline & $50 \mathrm{mg} / \mathrm{kg}$ & $120 \mathrm{mg} / \mathrm{kg}$ & $4134^{\mathrm{dn}} \pm 51$ & $76 \%$ & $4524^{\text {do }} \pm 33$ & $80 \%$ & $4026^{\mathrm{cm}} \pm 58$ & $72 \%$ \\
\hline \multirow[t]{2}{*}{$0.4 \mathrm{ml} / \mathrm{kg}$} & $0.4 \mathrm{ml} / \mathrm{kg}$ & $0.8 \mathrm{ml} / \mathrm{kg}$ & $1860^{\mathrm{am}} \pm 53$ & $41 \%$ & $2325^{\text {bo }} \pm 37$ & $45 \%$ & $2093^{\text {an }} \pm 36$ & $45 \%$ \\
\hline & $1.0 \mathrm{ml} / \mathrm{kg}$ & $2.0 \mathrm{ml} / \mathrm{kg}$ & $3827^{\mathrm{cm}} \pm 40$ & $72 \%$ & $4212^{\mathrm{cn}} \pm 37$ & $77 \%$ & $3780^{\mathrm{bm}} \pm 31$ & $70 \%$ \\
\hline
\end{tabular}

Table 3: Effects of stimulants and temperature on fertilization rate of eggs of Clarias batrachus.

Values (mean $\pm S D$ ) within columns indicated by different superscript letters $(a, b, c, d)$ and values (mean $\pm S D)$ within rows indicated by different superscript letters ( $m$, $n, 0$ ) are significantly different (DMRT, $p<0.05)$.

\begin{tabular}{|c|c|c|c|c|c|c|c|c|}
\hline \multirow{3}{*}{\begin{tabular}{|l|} 
Name of stimulant \\
Pituitary gland extract
\end{tabular}} & \multirow{3}{*}{\begin{tabular}{|l|} 
Dose \\
Male \\
$25 \mathrm{mg} / \mathrm{kg}$ \\
\end{tabular}} & \multicolumn{7}{|c|}{ Mean No. of hatchlings and rate of hatching (\%) } \\
\hline & & \multirow{2}{*}{\begin{tabular}{|l|} 
Female \\
$40 \mathrm{mg} / \mathrm{kg}$ \\
\end{tabular}} & \multicolumn{2}{|l|}{$26^{\circ} \mathrm{C}$} & \multicolumn{2}{|l|}{$28^{\circ} \mathrm{C}$} & \multicolumn{2}{|l|}{$30^{\circ} \mathrm{C}$} \\
\hline & & & $1525^{\mathrm{am}} \pm 40$ & $36 \%$ & $2319^{\text {bo }} \pm 31$ & $52 \%$ & $2014^{\text {bn }} \pm 43$ & $45 \%$ \\
\hline & $50 \mathrm{mg} / \mathrm{kg}$ & $20 \mathrm{mg} / \mathrm{kg}$ & $3590^{\mathrm{cn}} \pm 33$ & $66 \%$ & $4032^{\text {do }} \pm 54$ & $71 \%$ & $3411^{\mathrm{dm}} \pm 50$ & $61 \%$ \\
\hline \multirow[t]{2}{*}{ Ovaprim } & $0.4 \mathrm{ml} / \mathrm{kg}$ & $0.8 \mathrm{ml} / \mathrm{kg}$ & $1555^{\mathrm{am}} \pm 32$ & $34 \%$ & $2163^{\text {ao }} \pm 32$ & $46 \%$ & $1640^{\text {an }} \pm 34$ & $35 \%$ \\
\hline & $1.0 \mathrm{ml} / \mathrm{kg}$ & $2.0 \mathrm{ml} / \mathrm{kg}$ & $2870^{\mathrm{bm}} \pm 37$ & $54 \%$ & $3546^{c n} \pm 26$ & $65 \%$ & $2825^{\mathrm{cm}} \pm 26$ & $52 \%$ \\
\hline
\end{tabular}

Table 4: Effects of stimulants and temperature on hatching rate of eggs of Clarias batrachus.

Values (mean $\pm S D$ ) within columns indicated by different superscript letters $(a, b, c, d)$ and values (mean \pm SD) within rows indicated by different superscript letters ( $m, n, 0$ ) are significantly different (DMRT, $p<0.05)$.

\begin{tabular}{|c|c|c|c|c|c|c|c|c|c|c|}
\hline \multirow{2}{*}{$\begin{array}{l}\text { Times of } \\
\text { day }\end{array}$} & \multicolumn{2}{|l|}{ pH } & \multicolumn{2}{|l|}{ Outdoor } & \multicolumn{2}{|l|}{$\mathrm{CO}_{2}(\mathrm{mg} / \mathrm{l})$} & \multicolumn{2}{|l|}{ DO (mg/l) } & \multicolumn{2}{|c|}{ Total alkalinity (mg/l) } \\
\hline & $\begin{array}{l}\text { Indoor } \\
\text { condition }\end{array}$ & $\begin{array}{l}\text { Outdoor } \\
\text { condition }\end{array}$ & $\begin{array}{l}\text { Indoor } \\
\text { condition }\end{array}$ & $\begin{array}{l}\text { Outdoor } \\
\text { condition }\end{array}$ & $\begin{array}{l}\text { Indoor } \\
\text { condition }\end{array}$ & $\begin{array}{l}\text { Outdoor } \\
\text { condition }\end{array}$ & $\begin{array}{l}\text { Indoor } \\
\text { condition }\end{array}$ & $\begin{array}{l}\text { Outdoor } \\
\text { condition }\end{array}$ & $\begin{array}{l}\text { Indoor } \\
\text { condition }\end{array}$ & \\
\hline $04.00 \mathrm{~h}$ & $7.6^{\mathrm{am}} \pm 0.2$ & $7.60^{\mathrm{bm}} \pm 0.6$ & $27.53^{\mathrm{am}} \pm 1.00$ & $27.33^{\mathrm{am}} \pm 1.05$ & $12.20^{\mathrm{am}} \pm 3.0$ & $12.00^{\mathrm{am}} \pm 4.0$ & $6.41^{\mathrm{cm}} \pm 0.50$ & $6.56^{\mathrm{dn}} \pm 0.32$ & $145.0^{\mathrm{am}} \pm 6.0$ & $148.0^{\mathrm{dm}} \pm 5.0$ \\
\hline $10.00 \mathrm{~h}$ & $7.50^{\mathrm{am}} \pm 0.5$ & $7.30^{\mathrm{abm}} \pm 0.3$ & $28.13^{\mathrm{bm}} \pm 0.75$ & $29.63^{\mathrm{bn}} \pm 1.25$ & $18.20^{\mathrm{bm}} \pm 3.0$ & $23.30^{\mathrm{bn}} \pm 4.0$ & $6.22^{\mathrm{bn}} \pm 0.50$ & $5.27^{\mathrm{cm}} \pm 0.75$ & $140.0^{\mathrm{am}} \pm 4.0$ & $135.0^{\mathrm{cm}} \pm 5.0$ \\
\hline $16.00 \mathrm{~h}$ & $7.40^{\mathrm{am}} \pm 0.6$ & $7.10^{\mathrm{am}} \pm 0.2$ & $28.20^{\mathrm{cm}} \pm 1.25$ & $29.95^{\mathrm{cn}} \pm 1.05$ & $23.90^{\mathrm{dm}} \pm 1.05$ & $35.00^{d n} \pm 3.0$ & $5.90^{\text {an }} \pm 0.72$ & $4.95^{\mathrm{bm}} \pm 0.56$ & $138.0^{\text {an }} \pm 4.0$ & $120.0^{\text {an }} \pm 6.0$ \\
\hline $22.00 \mathrm{~h}$ & $7.60^{\text {an }} \pm 0.4$ & $7.20^{\mathrm{am}} \pm 0.4$ & $28.00^{d m} \pm 1.15$ & $29.56^{\mathrm{bn}} \pm 0.70$ & $20.10^{\mathrm{cm}} \pm 0.70$ & $30.6^{\mathrm{cn}} \pm 0.70$ & $6.32^{\mathrm{cn}} \pm 0.70$ & $4.53^{\mathrm{am}} \pm 0.68$ & $140.0^{\text {an }} \pm 0.68$ & $128.0^{\mathrm{bm}} \pm 0.68$ \\
\hline
\end{tabular}

Table 5: Diurnal fluctuation of different physicochemical parameters of rearing medium in Indoor and Outdoor Experiments during rearing from $13^{\text {th }}$ to $45^{\text {th }}$ day.

Values (mean \pm SD) within columns indicated by different superscript letters (a,b,c,d) and values (mean \pm SD) within rows indicated by different superscript letters (m,n) are significantly different (DMRT, $p<0.05$ ). 
Citation: Dhara K, Saha NC (2013) Controlled Breeding of Asian Catfish Clarias batrachus using Pituitary Gland Extracts and Ovaprim at different Temperatures, Latency Periods and their Early Development. J Aquac Res Development 4: 186 doi:10.4172/2155-9546.1000186

Page 6 of 9

\begin{tabular}{|l|l|l|l|}
\hline Feeding trial Set & Feed schedule & $\begin{array}{l}\text { Survival rate (\%) at Indoor } \\
\text { condition }\end{array}$ & $\begin{array}{l}\text { Survival rate (\%) at Indoor } \\
\text { condition }\end{array}$ \\
\hline Set I & Live zooplankton & $58.3^{\text {bn }} \pm 2.07$ \\
\hline Set II & $\begin{array}{l}\text { Alternate use of live zooplankton, boiled egg with little amount of vitamin C } \\
\text { and chopped tubifex }\end{array}$ & $82.5^{\mathrm{cm}} \pm 2.25$ & $47.6^{\mathrm{am}} \pm 3.86$ \\
\hline Set III & $\begin{array}{l}\text { Finely powered rice bran, bran, mustard oil cake and trash fish mixture } \\
(1: 1: 1)\end{array}$ & $51.9^{\mathrm{an}} \pm 3.37$ & $70.0^{\mathrm{bm}} \pm 1.89$ \\
\hline
\end{tabular}

Table 6: Survival rate (\%) of developing Clarias batrachus in indoor and outdoor experiments during rearing from $13^{\text {th }}$ to $45^{\text {th }}$ day using various feed schedule. Values (mean $\pm S D$ ) within columns indicated by different superscript letters $(a, b, c)$ and values (mean \pm SD) within rows indicated by different superscript letters ( $m, n$ ) are significantly different (DMRT, $p<0.05)$

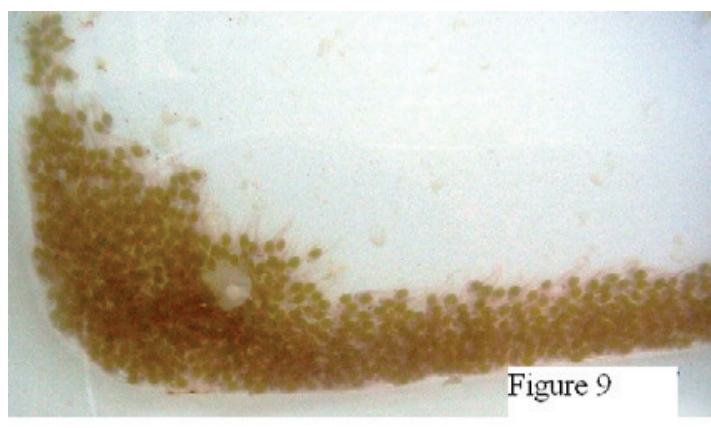

Figure 9: 2 day's old developing C. batrachus.

7 hours: Embryo formation within egg capsule was almost completed.

10 hours: Head and tail ends of the embryo were differentiated.

20 hours: Embryo started twitching movement within egg capsule.

21 hours: A thin line of brown-red colour was recorded from head to tail end of the embryo.

22-23 hours: Twitching movement of the embryo was frequent and its tail end became free. The eggs were oval in shape.

26-27 hours: Spawn hatched out rupturing egg membrane.

\section{Newly hatched fish}

The mean length was $4.10 \pm 0.40 \mathrm{~mm}$ and mean weight was 3.00 $\pm 0.29 \mathrm{mg}$. The body was yellowish and laterally compressed. The yolk sac was large and ovoid with a mean length $2.10 \pm 0.04 \mathrm{~mm}$ and mean height $1.50 \pm 0.03 \mathrm{~mm}$. The fish took rest at the bottom placing the body at any one side due to heavy load of yolk. The protruding head part of fish bended downwards and the free tail end lashed like a flagellum.

\section{1 day old fish}

Mean length of fish was $5.55 \pm 0.50 \mathrm{~mm}$ and mean weight was 3.95 $\pm 0.38 \mathrm{mg}$. The yolk sac was large and the mean length and height of the sac were $2.10 \pm 0.03 \mathrm{~mm}$ and $1.50 \pm 0.04 \mathrm{~mm}$ respectively. Fish was straw yellow in colour with transparent body and dark pigmented eye. A slit like mouth appeared in this stage. The alimentary canal started to appear as a straight tube like structure in the post dorsal region of the yolk sac. The fish remained confined to the bottom and started body movement lashing the tail.

\section{2-4 days old fish}

At day 2, the mean length and mean weight of fish were $6.25 \pm 0.90$ $\mathrm{mm}$ and $4.75 \pm 0.66 \mathrm{mg}$ respectively. The yolk sac started to reduce (mean length $2.00 \pm 0.04 \mathrm{~mm}$ and mean height $1.40 \pm 0.03 \mathrm{~mm}$ ). The head of developing fish became prominent with fully pigmented large eye and minute developing barbels. The body was more pigmented on the edge part especially on the cephalic region. The pigmentation appeared in rows over the body. Two fine red vessels appeared along the ventral side of the yolk sac. At day 3, the barbels were prominent and pectoral fin bud appeared. At day 4, the gill region became reddish in colour. The barbels were more prominent. The fish moved swiftly and preferred to hide in a darker corner of the tray (Figure 9).

\section{5-9 day's old fish}

At day 5, the mean length was $8.75 \pm 0.40 \mathrm{~mm}$ and mean weight was $9.09 \pm 0.71 \mathrm{mg}$. Yolk sac was absent. Pigmentation appeared all over the body. The fish became reddish brown in colour. Head was provided with 4 pairs of distinct barbels. Pectoral fin with fin rays was well developed, dorsal and anal fins were continuous with caudal fin. The fish preferred to hide in the corner of the tray. On day 6, ventral fin buds were found. No significant change was recorded upto day 9 excepting length and weight.

\section{0-15 days old fish}

At day 10, the mean length and mean weight were $13.00 \pm 1.00 \mathrm{~mm}$ and $25.71 \pm 0.74 \mathrm{mg}$ respectively. The body was light reddish brown in colour. The dorsal and anal fins were separated from the caudal fin. Well developed ventral fin and dorsal fin with 4 fin rays in each were noticed. No significant change was observed upto $15^{\text {th }}$ day excepting length and weight. At day 14, fish started vertical movements and at day 15, both vertical and horizontal movements of the fish were noted (Figure 10).

\section{6-27 days old fish}

At day 16, the mean length of fish was $17.08 \pm 1.05 \mathrm{~mm}$ and mean weight was $40.50 \pm 0.80 \mathrm{mg}$. Caudal fin became homocercal and spine developed in the pectoral fin. At day 20, osseous plates on the cephalic region were distinctly observed in the fish body. No other significant morphological changes were recorded upto day 27 (Figure 11).

\section{0 days old fish}

The mean length was $38.00 \pm 1.00 \mathrm{~mm}$ and mean weight was 397.00 $\pm 0.73 \mathrm{mg}$. Fish changed their body colour from light to dark reddish brown. The osseous plates appeared at this stage on the cephalic region (Figure 12).

\section{5 days old fish}

The recorded mean length and weight were $65.00 \pm 3.00 \mathrm{~mm}$ and $1500 \pm 27.50 \mathrm{mg}$ respectively. At this stage fish was elongated and provided with all morphological characters like an adult. The fish was dark reddish brown in colour. The well formed osseous plates were recorded on the moderately sized dorso-ventrally flattened head. Two depressions were found on the head. The mouth was terminal, transverse and wide. The fish preferred to stay in the resting state with an angle of $20^{\circ}-60^{\circ}$ touching the bottom with caudal fin during most of 
Citation: Dhara K, Saha NC (2013) Controlled Breeding of Asian Catfish Clarias batrachus using Pituitary Gland Extracts and Ovaprim at different Temperatures, Latency Periods and their Early Development. J Aquac Res Development 4: 186 doi:10.4172/2155-9546.1000186

Page 7 of 9

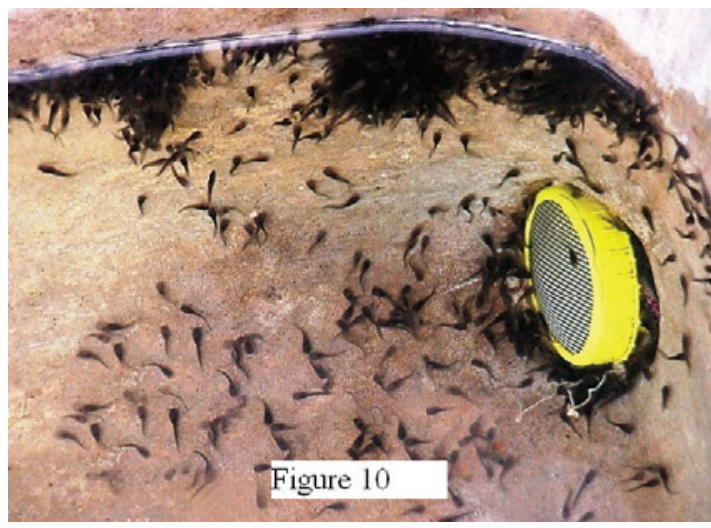

Figure 10: 12 day's old developing C. batrachus.

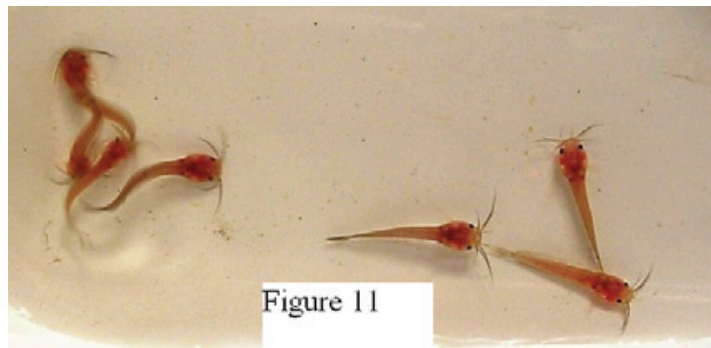

Figure 11: 23 day's old developing C. batrachus.

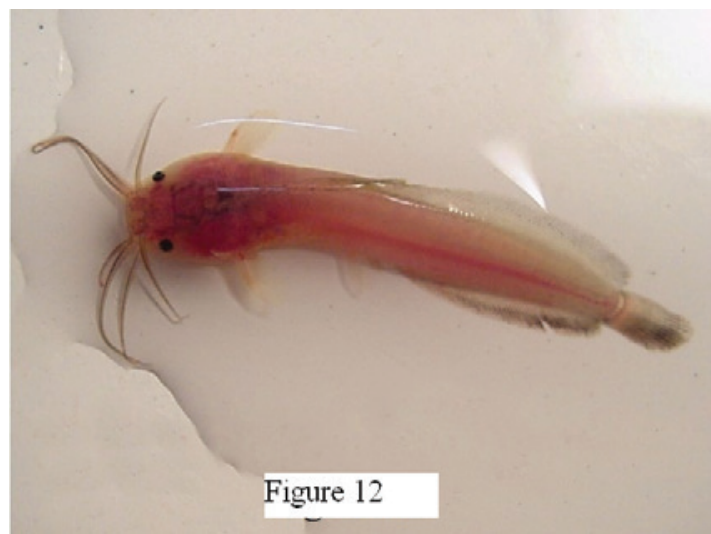

Figure 12: 30 day's old developing C. batrachus.

the day time but occasionally came to surface water for engulfing air. Frequent movement of fish was observed at night.

\section{Discussion}

In the present study, the higher doses of pituitary gland extracts $(120 \mathrm{mg} / \mathrm{kg}$ body weight for female and $50 \mathrm{mg} / \mathrm{kg}$ body weight for male) and Ovaprim $(2.0 \mathrm{ml} / \mathrm{kg}$ body weight for female and $1.0 \mathrm{ml} / \mathrm{kg}$ body weight for male) caused significantly higher rate of egg release, fertilization and hatching over the lower doses of stimulants irrespective of temperatures probably due to the full maturity of eggs without any cluster and fully developed testes with higher percentage of motile and viable sperms in males (Tables 1, 3 and 4). Similar results were also recorded by various workers using higher doses of Ovaprim [1] and carp pituitary gland extracts $[6,25,26]$ in Clarias sp. Spawning of $C$. batrachus at higher doses (100-150 mg/ $\mathrm{kg}$ body weight of female) of carp pituitary gland extracts was also observed by Sidthimunka et al. [25], Khan and Mukhopadhyay [26]. Sahoo et al. [27] also used higher doses of inducing agents during late monsoon breeding operation to get higher success in induced breeding of Clarias batrachus.

In this investigation best result in respect of egg release, fertilization and hatching of egg was obtained in the fish treated with higher doses of pituitary gland extracts (Tables 1, 3 and 4 ). This is probably due to the proper activation of Gonadotropin hormone-II (GTH-II) cell present in the Pars distalis of the treated fish which in turn helps in the proper secretion of GTH-II. The secreted GTH-II binds to the specific receptor in the granulose cells of ovary or Leydig cells of testis and subsequently stimulates steroid hormone synthesis in these cells resulting in the better ovulation and spermiation [28]. Another probable explanation for obtaining better results from fish injected with higher doses of pituitary gland extracts or Ovaprim is that the stimulants in higher doses stimulate the fish effectively by contracting the smooth muscles in the gonoduct of female before ovulation and thinning of semen just before spermiation in male, culminating in spawning of fish [29]. The poor responses at lower doses of both pituitary gland extracts $(40 \mathrm{mg} /$ $\mathrm{kg}$ body weight for female) and Ovaprim $(0.8 \mathrm{ml} / \mathrm{kg}$ body weight for female) may be due to insufficient secretion of gonadotropin leading to ovulation failure or blocking of ovipore by disintegrated ovarian tissue and egg bunches [10].

Zonneveld et al. [30] reported that right combination of the dose of inducing agent and the latency period plays the crucial role in the production of optimum quantity of eggs in catfish. Improper combination of these two may lead to breeding failure [11]. In present study, 14 to 15 hours latency period was most congenial for smooth release of fully matured eggs from the fish treated with higher dose of pituitary gland extracts leading to higher success in fertilization and hatching irrespective of all temperatures (Table 2). This result corresponds with the findings of Srivastava et al. [7]. They obtained better ovulation in C. batrachus using ovaprim $(1.0-2.0 \mathrm{ml} / \mathrm{kg}$ body weight of female) with a latency period of 14-18 hours. Higher stripping responses in C. batrachus were also observed by Sahoo et al. [11] at 3000 and 4000 IU HCG in combination with 14-23 hour slatency period. Comparatively poor breeding performance of $C$. batrachus at the latency period of 13 hours recorded in the present investigation may be due to inadequate release of gonadotropin and insufficient time for ovulation $[11,31]$. On the other hand lower success rate in fertilization and hatching of eggs during higher latency periods (16-17 hours) was probably due to over-ripe eggs which can not be ruled out by hormonal induction [27].

Highest rate of fertilization and hatching at $28^{\circ} \mathrm{C}$ in all treatments in the present study was may be due to the fact that this temperature played an important role to optimize all the physiological activities of the stimulant injected fish. Temperature specificity of different fish during sexual maturation and spawning was also recorded by many workers [32-36].

During rearing of young developing fish, higher survival rate was noticed in the smooth surfaced indoor PVC tray than the outdoor cement cistern. Marked diurnal fluctuations of temperature, free carbon dioxide and dissolved oxygen concentrations in the rearing medium of outdoor cistern exerts stress to the developing fish leading to increased rate of mortality. Consistency in higher level of dissolved oxygen concentration in the indoor rearing medium played the key role in maintaining higher survival rate of developing fish. High 
Citation: Dhara K, Saha NC (2013) Controlled Breeding of Asian Catfish Clarias batrachus using Pituitary Gland Extracts and Ovaprim at different Temperatures, Latency Periods and their Early Development. J Aquac Res Development 4: 186 doi:10.4172/2155-9546.1000186

hatchability and survival of developing young African catfish at higher concentration of dissolved oxygen were also observed by various workers $[37,38]$. Higher fluctuation in dissolved oxygen concentration in outdoor cistern was due to comparatively higher water temperature. Higher temperature decreases the dissolved oxygen concentration by reducing its solubility in water [39].

The developing C. batrachus showed better survival when they were fed with zooplankton as live feed alternately with boiled egg and chopped tubifex. This result corresponds with the findings of earlier workers $[2,40]$.

The fertilized eggs of $C$. batrachus were adhesive in nature which was similar to those of other catfish species such as Mystus montanus, Pangasius sutchi, Heteropneustus fossilis $[15,41,42]$. This represents an adaptation to prevent the flowing of eggs in the water currents and provide optimal oxygen supply [15]. The average diameter of fully swollen fertilized egg of $C$. batrachus as recorded in the present study was $1.80 \pm 0.05 \mathrm{~mm}$ which was more or less similar in size (1.5-1.9 $\mathrm{mm})$ as observed by the earlier workers $[17,43,44]$. In the present investigation, the fertilized eggs were yellowish brown in colour which corresponds with the findings of Khan [45] and Thakur et al. [44]. In this study, time required for hatching of eggs after fertilization was gradually decreased with increasing environmental temperature irrespective of type and doses of the stimulants. Zaki and Abdula [46] and Herath [47] also observed shorter incubation period at higher temperatures. The present observation on the mean length of the newly hatched fish $(4.10 \pm 0.40 \mathrm{~mm})$ corresponds with the results $(4.5-4.7 \mathrm{~mm})$ of Thakur [17]. The observation of Mookerjee and Mazumder [16] on length of newly hatched C. batrachus was slightly higher $(5.8 \mathrm{~mm})$ than our present records. Observation of Thakur [17] on the length and height of yolk sac (2.1 and $1.6 \mathrm{~mm}$ respectively) was similar to the present findings ( 2.1 and $1.5 \mathrm{~mm}$ respectively). The complete absorption of yolk sac in developing C. batrachus was recorded on 5th day in the present study which was similar with the observation of Thakur [17]. In this investigation, first vertical movement of developing fish was recorded on $11^{\text {th }}$ day probably due to the formation of aerial respiratory organ. Thakur [17] observed the vertical movement of fish in C. batrachus on 10th day. In the present study, fish showed active movement on 11th day onwards probably due to the development of extended and free caudal fin which was almost similar with the findings of Puvaneswari et al. [15] on Heteropneustes fossilis where free movement of the developing fish started on the $10^{\text {th }}$ day. All morphological characters of the adult $C$. batrachus were distinctly observed in the young developing fish in the present study on $20^{\text {th }}$ day. On the other hand, Thakur [17] stated that most of the adult characters in C. batrachus appeared by $15-20^{\text {th }}$ day whereas Hossain et al. [2] observed the same on $18^{\text {th }}$ day. This variability in appearing all morphological characters in C. batrachus may be due to availability of proper and adequate food with optimum physicochemical properties of the rearing medium.

In the present study most successful results in respect of number of stripped out eggs, rate of fertilization and hatching were recorded in Clarias batrachus injected with carp pituitary gland extracts @ $50 \mathrm{mg} /$ $\mathrm{kg}$ body weight of male and $120 \mathrm{mg} / \mathrm{kg}$ body weight of female at $28^{\circ} \mathrm{C}$. The highest survival rate of developing fish can be achieved by applying zooplankton as live feed upto $12^{\text {th }}$ day followed by alternate supply of zooplankton, boiled egg with vitamin $\mathrm{C}$ and chopped tubifex upto $45^{\text {th }}$ day of rearing in indoor PVC tray. This breeding operation will provide some valuable information in the development of breeding technology of $C$. batrachus which will be very important for commercial hatcheries in respect of good quality seed collection. In addition, the chronological characterization of different developmental stages of the fish (fertilized egg to $45^{\text {th }}$ day old fish) recorded in the present study will also help the fishermen to know the developmental pattern of C. batrachus and to take the proper management practices during rearing of their most sensitive earlier stages.

\section{Acknowledgements}

We thank Dr. Amalendu Jana, Head, Postgraduate Department of Zoology and the Principal, Jhargram Raj College, Paschim Medinipur, West Bengal fo allowing us to carry out the research work. The authors are also thankful to the Director, Directorate of Fisheries, Govt. of West Bengal for the support during the work.

\section{References}

1. Mahapatra BK, Sengupta KK, De KK, Rana GC, Datta A, et al. (2000) Control breeding and larval rearing of Clarias batrachus (Linn.) for mass scale propagation. Fishing Chimes 19: 97-102.

2. Hossain Q, Hossain MA, Parween S (2006) Artificial breeding and nursery practices of Clarias batrachus (Linn). Scientific World 4: 32-37.

3. Kamal D, Khan AN, Rahman MA, Ahamed F (2007) Biochemical composition of some small indigenous fresh water fishes from the River Mouri, Khulna, Bangladesh. Pak J Biol Sci. 10: 1559-1561.

4. Sinha M (2010) Seed production of Indian magur through induced breeding: An avenue for diversification of aquaculture, conservation of indigenous ichthyofauna and utilization of unexplored aquatic resources. In: Book of Abstract of Golden Jubilee National Seminar on Diversification of Aquaculture through Locally Available Fish Species, 31, CIFE, Kolkata, Aug. 27-28, Kolkata, India.

5. Sahu AK, Sahoo SK, Ayyapan S (2000) Seed production and hatchery management: Asian Catfish Clarias batrachus. Fishing Chimes 19: 94-96.

6. Chondar SL (1999) Biology of finfish and shellfish. SCSC Publishers, India.

7. Srivastava PP, Raizada S, Dayal R, Chowdhary S, Lakra WS et al. (2012) Breeding and larval rearing of Asian Catfish, Clarias batrachus (Linn) on live and artificial feed. J Aquacult Res Dev 3: 134.

8. Basu D, Rana GC, Mondal BK, Sengupta KK, Dhar PK (2000) Studies on the comparative efficacy of Ovaprim, HCG and Piscine pituitary gland in induced breeding of Clarias batrachus (Linn). Fishing Chimes 19: 103-104.

9. Sahoo SK, Giri SS, Sahu AK (2005) Effect on breeding performance and egg quality of Clarias batrachus (Linn) at various doses of Ovatide during spawning induction. Asian Fisheries Science 18: 77-83.

10. Sahoo SK, Giri SS, Chandra S, Mohapatra BC (2008) Evaluation of breeding performance of Asian Catfish Clarias batrachus at different dose of HCG and latency period combinations. Turkish J Fish and Aqua Sci 8: 249-251.

11. Sahoo SK, Giri SS, Sahu AK (2006) Induced spawning of Asian Catfish Clarias batrachus (Linn): effects of various latency periods and SGnRHa and domperidone doses on spawning performance and egg quality. Aquaculture Research 36: 1273-1278

12. Mahapatra BK, Sardar P, Datta S (2010) Management norms for enhancing larval survivality of magur, Clarias batrachus (Linn). In: Book of Abstract Golden Jubilee National Seminar on Diversification of Aquaculture through Locally Available fish species, CIFE, 37, Kolkata.

13. Saha R (1996) Effects of various doses of Ovaprim for breeding of Clarias spp. in Tripura. J Inland Fish Soc India 28: 75-84

14. Goswami UC, Sarma NN (1997) Pituitary dose optimization for induced ovulation, in vitro fertilization and production of normal fry of Clarias batrachus (Linn). J Asian Fisheries Science 10: 163-167.

15. Puvaneswari S, Marimuthu K, Karuppaswmy R, Haniffa MA (2009) Early embryonic and larval development of Indian catfish, Heteropneustes fossilis. EurAsia J BioSci 3: 84-96.

16. Mookerjee HK, Mazumdar SR (1950) Some aspects of the life history of Clarias batrachus (Linn). Proceedings of Zoological Society of Bengal 3: 71-79.

17. Thakur NK (1980) Notes on the embryonic and larval development of the air breathing catfish Clarias batrachus (Linn.). J Inland Fish Soc India 12: 30-43.

18. Das SK (2002) Seed production of Magur (Clarias batrachus) using a rura 
Citation: Dhara K, Saha NC (2013) Controlled Breeding of Asian Catfish Clarias batrachus using Pituitary Gland Extracts and Ovaprim at different Temperatures, Latency Periods and their Early Development. J Aquac Res Development 4: 186 doi:10.4172/2155-9546.1000186

model portable hatchery in Assam, India-a farmer proven technology. Aquaculture Asia VII: 19-21

19. Bhowmick RM (1990) Hypophysation of Indian and exotic carps. In: Sugunan VV, Bhaumik U (eds), Technologies for Inland Fisheries Development, Centra Inland Capture Fisheries Research Institute, ICAR, Barrackpore, West Bengal: $15-24$

20. Nandeesha MC, Keshavanath P, Varghese TJ, Shetty HPC, Gopal Rao K (1990) Alternate inducing agents for carp breeding: Progress in Research. In: Keshavnath P, Radhakrishnan KV (Eds) Carp seed Production technology, Special Publication, Asian Fisheries Soc, Indian Branch: 2: 12-15.

21. Nandeesha MC, Gopal Rao K, Jayanna RN, Parkar NC, Varghese TJ et al. (1990) Induced spawning of Indian major carps through single application of Ovaprim-C. In: Hirano R, Hanyo I (eds), Proceedings of Second Asian Fisheries Forum, Asian Fisheries Soc, Philippines, 581-585.

22. American Public Health Association (APHA) (2000) Standard methods for the examination of water and wastewater. (21stedn), APHA-AWWA-WEF, Pub: APHA, Washington DC, USA, 1268.

23. Crawford CM (1986) Development of eggs and larvae of the flounders Rhombosolea tapirina and Ammotectis rotratus (Pisces: Pleuronectidae). J Fish Biol 29: 325-334.

24. Gomez KA, Gomez AA (1984) Statistical procedures for agricultural research $\left(2^{\text {edn }}\right)$ John Wiley and Sons, New York, pp: 296.

25. Sidthimunka, A., Sanglert, J. and Pawaputanon, O (1966) The culture of catfish (Clarias spp.) in Thailand, Proceedings of the World Symposium on Warmwater Fish Culture, Rome, May 1966. FAO Fisheries Report No. 44: 196-04.

26. Khan HA, Mukhopadhyay SK (1975) Production of stocking material of some air-breathing fishes by hypophysation. J Inland Fish Soc India, VII: 156-161.

27. Sahoo SK, Giri SS, Swain T, Sahu AK (2004) Observations on some common abnormalities in induced bred Clarias batrachus hatchlings. J Inland Fish Soc India 36: 67-71.

28. Kraak GVD, Chang JR, Janz DM (1998) Reproduction In: Evans DH (eds), The Physiology of Fishes. (2ndedn), CRC Press, USA.

29. Smith LS (1999) Reproduction In: Introduction to Fish Physiology. Narendra Publishing House, Delhi, 266.

30. Zonneveld N, Rustidja WJ, Viveen AR, Maduna W (1988) Induced spawning and egg incubation of Asian Catfish, Clarias batrachus. Aquaculture 74: 41-47.

31. Tan-Fermin JD, Pogador RR, Chavez RC (1997) LHRHa and pimozide-induced spawning of Asian Catfish Clarias macrocephalus (Gunther) at different times during an annual reproduction cycle. Aquaculture 148: 323-331.
32. Khan H (1945) Observations on the spawning behaviour of carp in Punjab. Proc Nat Inst Sci India 11: 315-320.

33. Pickford GE, Atz JW (1957) The Physiology of the Pituitary Glands of Fishes. New York Zoological Society, New York.

34. Choudhury H (1960) Experiments on induced spawning of Indian carps with pituitary injections. Indian J Fish 7: 20-48.

35. Choudhury $H$ (1968) Breeding and selection of cultivated warm water fishes in Asia and the Far East - A review. FAO Fish Rep 44: 30-66.

36. Tripathy SD, Khan HA (1990) Carp seed production technology - A review In: Keshavanath P, Radhakrishnan KV (Eds), Carp Production Technology. Special Publication. Asian Fish Soc, Indian Branch 2: 1-11.

37. Olumuji OK, Mustapha MK (2012) Induced Breeding of African Mud Catfish, Clarias gariepinus (Burchell 1822), using Different Doses of Normal Saline Diluted Ovaprim. J Aquacult Res Dev 3: 133

38. Nwadukwe FO (1993) Inducing oocytes maturation, ovulation and spawning in the African catfish, Heterobranchus longifilis Valenciennes (Pisces: Clariidae) using frog pituitary extract. Aquaculture Research 24: 625-630.

39. Boyd CE (1982) Water Quality. In: Water quality management for pond fish culture, Elsevier Scientific Publishing Company, Amsterdam, 34.

40. Alam MS, Mollah MFA (1988) Formulation of an artificial dry feed for primary nursing of catfish (Clarias batrachus L.) larvae. Bangladesh J Fish 11: 71-75.

41. Arockiaraj AJ, Haniffa MA, Seetharaman S, Sing SP (2003) Early development of a Threatened Freshwater catfish Mystus Montanus (Jerdon). Acta Zoologica Taiwanica 14: 23-32.

42. Islam A (2005) Embryonic and larval development of Thai pangas (Pangasius sutchi Fowler 1937). Dev Growth Differ 47: 1-6.

43. Mookerjee HK (1946) Identification of eggs of common freshwater fishes of Bengal. Sci \& Cult 11: 48

44. Thakur NK, Pal RN, Khan HA (1974) Embryonic and larval development of Heteropneustes fossilis (Bloch). J Inland Fish Soc India 6: 33-44.

45. Khan HA (1972) Induced breeding of air-breathing fishes. Indian Farming 22 $44-45$

46. Zaki MI, Abdula A (1983) The reproduction and development of Clarias gariepinus (Claridae) from Lake Manzala (Egypt). Journal of Ichthyology 23: 48-58.

47. Herath HKS (1988) Hybridization, early development of embryos and production characteristics of larvae of African Catfish Clarias gariepinus (Burchell) and Asian Catfish Clarias batrachus (Linnaeus). Master Thesis, Wageningen Agricultural University, Wageningen. 